\title{
PENGARUH APLIKASI PUPUK HAYATI DAN PUPUK PELENGKAP ALKALIS TERHADAP KEANEKARAGAMAN ARTHROPODA DAN INTENSITAS PENYAKIT PENTING PERTANAMAN SEMANGKA (Citrullus vulgaris Schard)
}

\section{THE EFFECT OF BIOLOGICAL FERTILIZER AND COMPLEMENTARY FERTILIZER APPLICATIONS ON ARTHROPOD DIVERSITY AND THE INTENSITY OF SIGNIFICANT PLANTS WATERMELON (Citrullus vulgaris Schard)}

\author{
Oryza Wahyu Setiawan ${ }^{1}$, Sudi Pramono ${ }^{2 *}$, Kus Hendarto ${ }^{1}$ dan Suskandini Ratih Dirmawati ${ }^{2}$ \\ ${ }^{1}$ Jurusan Agroteknologi Fakultas Pertanian Universitas Lampung, Bandar Lampung, Indonesia \\ ${ }^{2}$ Jurusan Proteksi Tanaman Fakultas Universitas Lampung, Bandar Lampung, Indonesia \\ *Email: sudi.pramono@fp.unila.ac.id \\ *Corresponding Author, Diterima: 6 Mei 2021, Direvisi: 25 Juni 2021, Disetujui: 3 Sep. 2021
}

\begin{abstract}
Watermelon cultivation can not be separated from insects and plant diseases that are influenced by the environment. The application of biological fertilizers and alkaline complementary fertilizers can cause different environmental conditions for the growth and development of arthropods and pathogens in watermelon cultivation. This study aims to determine the effect of liquid biofertilizer concentration, alkaline complementary fertilizer concentration, and the interaction of the two fertilizers on arthropod diversity and important disease intensity of watermelon planting. The results showed that the application of liquid biological fertilizer with a concentration of $15 \mathrm{ml} / \mathrm{l}$ was able to increase the diversity of arthropods with a diversity index value of 1.26 at 4 WAP and 1.74 at 7 WAP. The application of alkaline supplementary fertilizers with a concentration of $2 \mathrm{~g} / \mathrm{l}$ was able to increase the diversity of arthropods with an index value of 1.25 at 4 WAP and 1.78 at 7 WAP. The application of liquid biological fertilizer with a concentration of $30 \mathrm{ml} / \mathrm{l}$ was able to reduce the severity of Downy Mildew with a disease severity value of 48.94\% at 7 WAP. The provision of complementary alkaline fertilizers with a concentration of $2 \mathrm{~g} / \mathrm{l}$ was able to reduce the severity of Downy Mildew with a disease severity value of $43.45 \%$ at 7 WAP. Provision of liquid biological fertilizer with a concentration of $30 \mathrm{ml} / \mathrm{l}$ with alkaline complementary fertilizers with a concentration of $2 \mathrm{~g} / \mathrm{l}$ gave a significant interaction or in other words, fruit yield per plot weighing an average of $17.44 \mathrm{~kg}$.
\end{abstract}

Keywords: Arthropods, fertilizer, plant disease, watermelon.

\begin{abstract}
ABSTRAK
Usaha budidaya tanaman semangka tidak terlepas dari gangguan serangga dan penyakit tanaman yang dipengaruhi oleh lingkungan. Pemberian pupuk hayati dan pupuk pelengkap alkalis dapat menimbulkan kondisi lingkungan yang berbeda untuk pertumbuhan dan perkembangan arthropoda maupun patogen pada pertanaman semangka. Penelitian ini bertujuan untuk mengetahui pengaruh konsentrasi pupuk hayati cair, konsentrasi pupuk pelengkap alkalis, dan interaksi kedua pupuk tersebut terhadap keanekaragaman arthropoda dan intensitas penyakit penting
\end{abstract}


pertanaman semangka. Hasil penelitian menunjukkan bahwa pemberian pupuk hayati cair konsentrasi $15 \mathrm{ml} / \mathrm{l}$ mampu meningkatkkan keanekaragaman arthropoda dengan nilai indeks keanekaragaman sebesar 1,26 pada 4 MST dan 1,74 pada 7 MST. Pemberian pupuk pelengkap alkalis konsentrasi $2 \mathrm{~g} / 1$ mampu meningkatkan kenakearagaman arthropoda dengan nilai indeks sebesar 1,25 pada 4 MST dan 1,78 pada 7 MST. Pemberian pupuk hayati cair konsentrasi $30 \mathrm{ml} / 1$ mampu menekan keparahan penyakit downy mildew dengan nilai keparahan penyakit sebesar 48,94\% pada 7 MST. Pemberian pupuk pelengkap alkalis konsentrasi $2 \mathrm{~g} / 1$ mampu menekan keparahan penyakit downy mildew dengan nilai keparahan penyakit sebesar 43,45\% pada 7 MST. Pemberian pupuk hayati cair konsentrasi $30 \mathrm{ml} / 1$ dengan pupuk pelengkap alkalis konsentrasi $2 \mathrm{~g} / 1$ memberikan interaksi berpengaruh nyata atau dengan kata lain memiliki hasil produksi buah per petak rata-rata seberat $17,44 \mathrm{~kg}$.

Kata kunci : Arthropoda, penyakit tanaman, pupuk, semangka

\section{PENDAHULUAN}

Provinsi Lampung adalah salah satu sentra produksi semangka di Indonesia. Pada tahun 2018 Provinsi Lampung menghasilkan produksi semangka sebanyak 16.843 ton/ha (Badan Pusat Statistik, 2018). Jumlah produksi tersebut merupakan 3,49 \% dari produksi semangka Nasional. Lampung menduduki posisi ketujuh sebagai Provinsi produsen semangka di Indonesia (Badan Pusat Statistik, 2018).

Usaha budidaya tanaman semangka tidak terlepas dari gangguan serangga. Serangga penting semangka ialah lalat pengorok daun, kutu kebul, dan lalat buah. Gangguan serangga ini disebabkan karena adanya hubungan antara tanaman dengan serangga yang sangat ditentukan oleh kandungan fitokimia tanaman yang dibutuhkan oleh serangga (Richard et al., 2015). Kehadiran suatu jenis serangga dalam suatu habitat juga dipengaruhi oleh faktor-faktor lingkungan antara lain kemampuan serangga untuk menyebar, seleksi habitat, kondisi suhu udara, kelembaban udara, kelembaban tanah, cahaya, curah hujan, vegetasi, dan ketersediaan makanan (tanaman inang/mangsa) (Subekti, 2012). Berdasarkan fungsinya, kehadiran serangga pada tanaman dapat dikelompokkan sebagai herbivora, polinator, predator, dekomposer dan parasitoid (Alao et al., 2016).

Serangga memiliki kemampuan adaptasi yang baik terhadap lingkungan habitatnya. Kemampuan serangga dalam beradaptasi di habitat barunya ditentukan oleh sumber daya yang tersedia yakni tumbuhan, sehingga menyebabkan keanekaragaman dan kelimpahan serangga pada suatu tanaman. Gichimu et al. (2008), menyatakan bahwa kelimpahan serangga akan berkurang ketika sumber makanan, tempat berlindung, tempat kawin, dan faktor lingkungan lainnya tidak mencukupi.

Masalah lain yang timbul dalam usaha budidaya tanaman semangka adalah penyakit tanaman. Penyakit tanaman adalah keadaaan fisiologi tanaman yang terganggu oleh patogen yang menyerang tanaman tersebut. Patogen yang menyerang tanaman adalah jamur, bakteri, virus. Patogen tanaman dapat mengganggu fungsi sel dan jaringan tumbuhan akibat iritasi yang terus menerus oleh suatu agen primer atau faktor lingkungan yang kemudian menimbulkan gejala (Ginting, 2013). 
Grikulan plus merupakan pupuk hayati cair yang bisa digunakan untuk menambah asupan nutrisi tanaman. Pupuk hayati cair ini banyak mengandung mikroorganisme yang berguna bagi tanaman, seperti mikroorganisme pelarut fosfat, mikroorganisme selulotik, Azospirillum sp., Azotobacter sp., Lactobacillus sp., Pseudomonas sp., enzim seperti enzim alkaline fosfatese, enzim acid fosfatase, dan hormone indole acetic acid (Gunarto, 2015).

Plant Catalyst adalah pupuk pelengkap alkalis yang mengandung unsur hara lengkap. Unsur hara yang terkandung di dalam pupuk pelengkap ini adalah unsur hara makro dan unsur hara mikro yang dibutuhkan tanaman agar tumbuh sehat. Unsur hara makro yang terkandung dalam pupuk ini adalah N,P,K, Ca, Mg, dan S, sedangkan unsur hara mikro yang terkandung adalah Fe, Cl, Mn, Cu, Zn, Bo, Na, dan Mo. Pupuk pelengkap ini digunakan untuk melengkapi kebutuhan unsur hara tanaman yang tidak disediakan oleh pupuk dasar anorganik agar tanaman lebih sehat dan lebih tahan terhadap serangan hama penyakit, meningkatkan produktivitas, kualitas hasil tanaman, ramah lingkungan, bersifat alkalis, dan hasil tanaman bebas dari unsurunsur logam berat yang bersifat karsinogenetik (Tim Plant Catalyst, 2014).

Tujuan penelitian ini adalah untuk mengetahui pengaruh konsentrasi pupuk hayati cair terhadap indeks keanekaragaman arthropoda dan intensitas penyakit penting pertanaman semangka; pengaruh konsentrasi pupuk pelengkapalkalis terhadap indeks keanekaragaman arthropoda dan intensitas penyakit penting pertanaman semangka serta mengetahui interaksi konsentrasi pupuk hayati cair dan konsentrasi pupuk pelengkap alkalis terhadap indeks keanekaragam-an arthropoda dan intensitas penyakit penting pertanaman semangka.

\section{BAHAN DAN METODE}

Penelitian ini dilaksanakan Penelitian ini dilaksanakan di Desa Sukabanjar Kecamatan Gedong Tataan Kabupaten Pesawaran dari Oktober 2019 sampai Desember 2019. Penelitian menggunakan rancangan acak kelompok faktorial 2 faktor, yaitu faktor pertama pupuk hayati cair konsentrasi $0 \mathrm{ml} / 1,15 \mathrm{ml} / 1$, $30 \mathrm{ml} / \mathrm{l}$ dan faktor kedua pupuk pelengkap alkalis dosis $0 \mathrm{~g} / 1,1 \mathrm{~g} / 1,2 \mathrm{~g} / 1$ dengan tiga kali ulangan. Data yang diperoleh diuji dengan menggunakan uji barlet, uji nonaditifitas, dan uji normalitas. Apabila dari ketiga asumsi tersebut terpenuhi dilakukan analisis ragam. selanjutnya data yang diperoleh diolah dengan Uji Beda Nyata Terkecil (BNT) pada taraf á 5\%. Pengambilan arthropoda menggunakan metode pengambilan langsung, pitfall trap, yellow trap, sedangkan pengamatan intensitas penyakit tanaman dilakukan dengan mengamati gejala penyakit tanaman di lapangan.

Peubah yang diamati dalam penelitian ini meliputi keanekaragaman arthropoda, kemerataan arthropoda, kekayaan jenis arthropoda, kepadatan populasi relatif, keterjadian penyakit tanaman, keparahan penyakit tanaman, produksi buah.

(i) Keanekaragaman arthropoda

$$
\begin{aligned}
& \mathrm{H}^{`}=-\sum \mathrm{Pi} \ln \mathrm{pi} \\
& \text { pi }=\sum \text { ni/N }
\end{aligned}
$$

\section{Keterangan:}

$\mathrm{H}^{\prime} \quad$ = Indeks keanekaragaman Shannon Wiener

Pi = Proporsi individu yang ditemukan pada famili ke-i 


$$
\begin{array}{ll}
\mathrm{ni} & =\text { Jumlah individu pada famili ke-i } \\
\mathrm{N} & =\text { Jumlah total individu } \\
\mathrm{h} & =\text { Logaritma narutal }
\end{array}
$$

(ii) Kemerataan arthropoda

$$
\begin{aligned}
& \mathrm{E}=\mathrm{H}^{\prime} / \mathrm{H}^{\prime} \max \\
& \mathrm{H}^{\prime} \max \\
& =\ln \mathrm{S}
\end{aligned}
$$

keterangan:

$$
\begin{array}{ll}
\mathrm{E} & =\text { Indeks kemerataan }(0-1) \\
\mathrm{H}^{`} & =\text { Indeks keanekaragaman ShannonWiener }
\end{array}
$$

(iii) Kekayaan jenis arthropoda

$$
\operatorname{Dmg}=(\mathrm{S}-1) / \ln \mathrm{N}
$$

Keterangan:

Dmg = Indeks kekayaan jenis margalef

$\mathrm{S} \quad=$ Jumlah famili

$\mathrm{N}=$ Total individu dalam sampel

(iv) Kepadatan populasi relatif

$$
\mathrm{Pi}=\frac{n i}{N} \times 100 \%
$$

Keterangan:

$$
\begin{array}{ll}
\mathrm{P} & =\text { Kepadatan pupulasi relatif jeniskei } \\
\mathrm{n} & =\text { Kelimpahan jenis ke } 1 \\
\mathrm{~N} & =\text { Jumlah total seluruh individu }
\end{array}
$$

(v) Keterjadian Penyakit

$$
\mathrm{KP}=\frac{n}{N} \times 100 \%
$$

Keterangan:

KP: keterjadian penyakit

$\mathrm{n}$ : jumlah tanaman yang terserang

$\mathrm{N}: \quad$ jumlah tanaman yang diamati

(vi) Keparahan penyakit

$$
K P_{P}=\frac{\sum n \times V}{N \times Z} \times 100 \%
$$

Keterangan:

$\mathrm{KPp}=$ keparahan penyakit

$\mathrm{n} \quad=$ jumlah setiap bagian daun yang terserang dengan skor tertentu

$\mathrm{V}=$ nilai skor serangan pada setiap bagian daun yang terserang

$\mathrm{N} \quad=$ jumlah total bagian daun yang diamati

$\mathrm{Z} \quad=$ skor tertinggi

\section{HASIL DAN PEMBAHASAN}

Hasil penelitian menunjukkan bahwa pada pengamatan keanekaragaman arthropoda, perlakuan pupuk hayati cair dan pupuk pelengkap alkalis berpengaruh nyata terhadap keanekaragaman arthropoda pada 4 MST dan 7 MST. Pengamatan kemerataan arthropoda, perlakuan pupuk hayati cair berpengaruh nyata terhadap kemerataan arthropoda

Tabel 1. Skor keparahan penyakit

\begin{tabular}{cc}
\hline Skala & Kerusakan \\
\hline 0 & Daun tidak bergejala \\
1 & Daun bergejala 1-20\% \\
2 & Daun bergejala $21-40 \%$ \\
3 & Daun bergejala $41-60 \%$ \\
4 & Daun bergejala $>60 \%$ \\
\hline
\end{tabular}


pada 7 MST dan perlakuan pupuk pelengkap alkalis berpengaruh nyata terhadap kemerataan arthropoda pada 3 MST, 4 MST, dan 7 MST. Pengamatan kekayaan jenis arthropoda, perlakuan pupuk pelengkap alkalis berpengaruh nyata terhadap kekayaan jenis arthropoda pada 7 MST. Pengamatan keparahan penyakit, perlakuan pupuk hayati cair dan pupuk pelengkap alkalis berpengaruh nyata terhadap keparahan penyakit pada 7 MST. Pengamatan bobot buah, interaksi perlakuan pupuk hayati cair dan pupuk pelengkap alkalis berpengaruh nyata terhadap bobot buah per petak.
Hasil uji BNT pada tarafá 5\% menunjukkan bahwa perlakuan pupuk hayati cair dan perlakuan pupuk pelengkap alkalis berpengaruh nyata terhadap keanekaragaman arthropoda pada pengamatan 4 MST dan 7 MST. Keanekaragaman arthropoda digolongkan menjadi beberapa kategori yakni nilai rendah $(<1)$, sedang (1-3,22), dan tinggi (>3,22) (Fitriana, 2006). Perlakuan pupuk hayati cair konsentrasi $15 \mathrm{ml} / 1$ pada pengamatan 4 MST dan 7 MST menunjukkan nilai keanekaragaman tertinggi bila dibandingkan dengan perlakuan lainnya atau dengan kata lain pupuk hayati cair konsentrasi $15 \mathrm{ml} / 1$ mampu meningkatkan

Tabel 2. Nilai tengah keanekaragaman arthropoda pada tanaman semangka pada 4 MST dan 7 MST.

\begin{tabular}{ccc}
\hline \multirow{2}{*}{ Perlakuan } & \multicolumn{2}{c}{ Keanekaragaman arthropoda } \\
\cline { 2 - 3 } & $4 \mathrm{MST}$ & $7 \mathrm{MST}$ \\
\hline H0 (tanpa pupuk hayati) & $0,98 \mathrm{~b}$ & $1,77 \mathrm{a}$ \\
$\mathrm{H} 1$ (pupuk hayati $15 \mathrm{ml} / \mathrm{l})$ & $1,26 \mathrm{a}$ & $1,74 \mathrm{a}$ \\
$\mathrm{H} 2$ (pupuk hayati $30 \mathrm{ml} / \mathrm{l})$ & $0,93 \mathrm{~b}$ & $1,54 \mathrm{~b}$ \\
\hline BNT & 0,25 & 0,15 \\
\hline A0 (tanpa pupuk alkalis) & $0,96 \mathrm{~b}$ & $1,55 \mathrm{~b}$ \\
A1 (pupuk alkalis 1 g/l) & $0,95 \mathrm{~b}$ & $1,73 \mathrm{a}$ \\
A2 (pupuk alkalis 2 g/l) & $1,25 \mathrm{a}$ & $1,78 \mathrm{a}$ \\
\hline BNT & 0,25 & 0,15 \\
\hline
\end{tabular}

Tabel 3. Nilai tengah kemerataan arthropoda pada tanaman semangka pada 3, 4, dan 7 MST.

\begin{tabular}{cccc}
\hline \multirow{2}{*}{ Perlakuan } & \multicolumn{3}{c}{ Kemerataan arthropoda } \\
\cline { 2 - 4 } & $3 \mathrm{MST}$ & $4 \mathrm{MST}$ & $7 \mathrm{MST}$ \\
\hline $\mathrm{H} 0$ (tanpa pupuk hayati) & 0,63 & 0,64 & 0,72 \\
& $(1,28) \mathrm{a}$ & $(1,30) \mathrm{a}$ & $(1,35) \mathrm{a}$ \\
$\mathrm{H} 1$ (pupuk hayati $15 \mathrm{ml} / \mathrm{l})$ & 0,66 & 0,76 & 0,72 \\
& $(1,26) \mathrm{a}$ & $(1,37) \mathrm{a}$ & $(1,35) \mathrm{a}$ \\
$\mathrm{H} 2$ (pupuk hayati $30 \mathrm{ml} / \mathrm{l})$ & 0,78 & 0,65 & 0,65 \\
& $(1,38) \mathrm{a}$ & $(1,30) \mathrm{a}$ & $(1,30) \mathrm{b}$ \\
\hline BNT & 0,18 & 0,07 & 0,01 \\
\hline A0 (tanpa pupuk alkalis) & 0,53 & 0,64 & 0,65 \\
& $(1,17) \mathrm{b}$ & $(1,30) \mathrm{b}$ & $(1,31) \mathrm{c}$ \\
A1 (pupuk alkalis $1 \mathrm{~g} / \mathrm{l})$ & 0.75 & 0,64 & 0,70 \\
& $(1,36) \mathrm{a}$ & $(1,29) \mathrm{b}$ & $(1,34) \mathrm{b}$ \\
A2 (pupuk alkalis $2 \mathrm{~g} / \mathrm{l})$ & 0.85 & 0,77 & 0,74 \\
& $(1,39) \mathrm{a}$ & $(1,38) \mathrm{a}$ & $(1,36) \mathrm{a}$ \\
\hline BNT & 0,18 & 0,07 & 0,01 \\
\hline
\end{tabular}


keanekaragaman arthropoda. Perlakuan pupuk pelengkap alkalis konsentrasi $2 \mathrm{~g} / \mathrm{l}$ pada pengamatan 4MST dan 7 MST menunjukkan nilai keanekaragaman tertinggi bila dibandingkan dengan perlakuan lainnya atau dengan kata lain pupuk pelengkap alkalis konsentrasi 2 g/lmampu meningkatkan keanekaragaman arthropoda.. Suatu komunitas dikatakan mempunyai keanekaragaman jenis tinggi, jika komunitas didalamnya diisi oleh banyak spesies (jenis) dengan kemelimpahan yang sama atau sama. Sebaliknya, jika komunitas terdiri dari sedikit spesies, maka keanekaragamannya rendah (Soegianto, 1994).
Hasil uji BNT pada taraf $\alpha$ 5\% menunjukkan bahwa perlakuan pupuk hayati cair dan perlakuan pupuk pelengkap alkalis berpengaruh nyata terhadap kemerataan arthropoda pada pengamatan 3 MST, 4 MST, dan 7 MST. Perlakuan pupuk hayati cair konsentrasi $15 \mathrm{ml} / 1$ pada pengamatan $7 \mathrm{MST}$ menunjukkan nilai kemerataan tertinggi jika dibandingkan dengan perlakuan lainnya atau dengan kata lain pupuk hayati cair konsentrasi $15 \mathrm{ml} / 1$ mampu meningkatkan kemerataan arthropoda. Perlakuan pupuk pelengkap alkalis konsentrasi $2 \mathrm{~g} / 1$ pada pengamatan $3 \mathrm{MST}$, 4 MST dan 7 MST menunjukkan

Tabel 4. Nilai tengah kekayaan jenis arthropoda pada 7 MST

\begin{tabular}{cc}
\hline \multicolumn{1}{c}{ Perlakuan } & Kekayaan jenis arthropoda \\
& $7 \mathrm{MST}$ \\
\hline A0 (tanpa pupuk alkalis) & $2,12 \mathrm{~b}$ \\
A1 (pupuk alkalis 1 g/l) & $2,46 \mathrm{a}$ \\
A2 (pupuk alkalis 2 g/l) & $2,34 \mathrm{ab}$ \\
\hline BNT & 0,25 \\
\hline
\end{tabular}

Tabel 5. Data kelimpahan jumlah individu arthropoda pada 7 MST.

\begin{tabular}{lllccccccccc}
\hline No & \multicolumn{1}{c}{ Famili } & Peranan & H0A0 & H0A1 & H0A2 & H1A0 & H1A1 & H1A2 & H2A0 & H2A1 & H2A2 \\
\hline 1 & Carabidae & Predator & 0 & 1 & 0 & 0 & 0 & 1 & 0 & 0 & 0 \\
2 & Staphylinidae & Predator & 13 & 24 & 17 & 17 & 12 & 19 & 13 & 17 & 19 \\
3 & Chrysomelidae & Herbivora & 0 & 0 & 0 & 0 & 0 & 0 & 3 & 0 & 0 \\
4 & Coccinelidae & Predator & 0 & 0 & 0 & 0 & 1 & 0 & 0 & 0 & 0 \\
5 & Tephritidae & Herbivora & 10 & 5 & 4 & 8 & 6 & 6 & 4 & 4 & 5 \\
6 & Agromyzidae & Herbivora & 48 & 66 & 45 & 56 & 70 & 66 & 59 & 53 & 66 \\
7 & Culicidae & Polinator & 3 & 3 & 3 & 2 & 3 & 3 & 3 & 2 & 3 \\
8 & Acrididae & Herbivora & 1 & 3 & 0 & 0 & 3 & 1 & 1 & 0 & 4 \\
9 & Gryllidae & Herbivora & 2 & 5 & 13 & 29 & 22 & 4 & 2 & 13 & 12 \\
10 & Mantidae & Predator & 0 & 0 & 0 & 0 & 0 & 0 & 0 & 0 & 0 \\
11 & Formicidae & Predator/Simbion & 142 & 33 & 38 & 128 & 55 & 83 & 227 & 122 & 43 \\
12 & Vespidae & Polinator & 0 & 0 & 0 & 0 & 0 & 0 & 0 & 1 & 0 \\
13 & Aleyrodidae & Herbivora & 79 & 49 & 33 & 52 & 50 & 61 & 59 & 50 & 60 \\
14 & Alydidae & Herbivora & 4 & 4 & 2 & 0 & 3 & 6 & 0 & 1 \\
15 & Cicadellidae & Herbivora & 4 & 4 & 3 & 4 & 9 & 4 & 4 & 3 & 8 \\
16 & Carcinophoridae & Predator & 0 & 3 & 2 & 3 & 1 & 0 & 0 & 0 & 0 \\
17 & Crambidae & Herbivora & 1 & 4 & 2 & 4 & 1 & 2 & 2 & 3 & 2 \\
18 & Lycosidae & Predator & 5 & 8 & 3 & 2 & 1 & 7 & 2 & 4 & 2 \\
19 & Spirostreptidae & Dekomposer & 3 & 0 & 0 & 1 & 0 & 1 & 0 & 2 \\
20 & Gomphidae & Predator & 1 & 0 & 0 & 0 & 0 & 0 & 0 & 0 \\
21 & Libellulidae & Predator & 0 & 0 & 0 & 0 & 0 & 0 & 0 & 0 \\
22 & Entomobrydae & Dekomposer & 13 & 2 & 2 & 7 & 0 & 0 & 11 & 2 \\
23 & Rhinotermitidae & Herbivora & 3 & 2 & 2 & 8 & 4 & 4 & 5 & 8 \\
\hline & Jumlah & & 332 & 216 & 169 & 321 & 241 & 268 & 395 & 285 & 232 \\
\hline
\end{tabular}


nilai kemerataan tertinggi bila dibandingkan dengan perlakuan lainnya. Menurut. Oka(1995), semakin kecil nilai kemerataan, maka semakin besar jumlah suatu jenis arthropoda yang mendominasi di komunitas tersebut.

Kriteria komunitas berdasarkan indeks kekayaan jenis (Dmg) arthropoda yaitu $<2,5$ :Buruk, 2,5-4,0, Moderat > 4,0:Baik (Jorgensen et al., 2005 dalam Ardiyanti, 2019). Kekayaan jenis arthropoda pada pengamatan 7 MST perlakuan pupuk pelengkap alkalis konsentrasi $1 \mathrm{~g} / 1$ menunjukkan nilai tertinggijika dibandingkan dengan perlakuan pupuk pelengkap alkaliskonsentrasilainnya. Tambunan etal.(2013), mengatakan bahwa keadaaan iklim yang stabil menyebabkan kekayaan jenis arthropoda menjadi tinggi.

Berdasarkan hasil pengamatan kelimpahan arthropoda (Tabel 4) dan kepadatan populasi relatif arthropoda (Tabel 5) yang diberikan perlakuan pupuk hayati cair dan pupuk pelengkap alkalis. Perbedaan pemberian konsentrasi pupuk hayati cair dan pupuk pelengkap alkalis mempengaruhi kelimpahan individu dan kepadatan populasi relatif arthropoda. Perlakuan yang memiliki jumlah kelimpahan individu dan kepadatan populasi relatifarthropoda yang paling tinggi ada pada kombinasi perlakuan pupuk hayati cair konsentrasi $30 \mathrm{ml} / 1$ dengan pupuk pelengkap alkalis konsentrasi $0 \mathrm{~g} / 1$ (tanpa pupuk pelengkap alkalis), sedangkan pada kombinasi perlakuan pupuk hayati cair konsentrasi $30 \mathrm{ml} / 1$ dengan pupuk pelengkap alkalis konsentrasi $2 \mathrm{~g} / 1$ memiliki kelimpahan individu dan kepadatan populasi relatif arthropoda terkecil. Arthropoda yang ditemukan pada penelitian ini diduga berperan sebagai predator, herbivora, dekomposer, dan polinator pada pertanaman semangka. Kehadiran arthropoda dalam suatu habitat dipengaruhi vegetasi dan ketersediaan makanan bagi arthropoda tersebut (Subekti, 2012).

Pupuk hayati cair mengandung mikroorganisme seperti Azotobacter sp., Azospirilium sp., dan Lactobacillus sp. yang memiliki manfaat penting bagi tanaman (Gunarto, 2015). Dengan banyaknya populasi mikroorgansime-mikroorganisme tersebut, maka proses dekomposisi bahan anorganik di dalam tanah menjadi lebih aktif yang pada akhirnya memberikan suplai hara yang cukup bagi tanaman semangka, sehingga tanaman semangka tumbuh dan berkembang dengan baik (subur). Kondisi habitat seperti itu diduga mendukung keberadaan arthropoda pada perlakuan kombinasi pupuk hayati cair konsentrasi $30 \mathrm{ml} / 1$ dengan pupuk pelengkap alkalis konsentrasi $0 \mathrm{~g} / 1$.

Pemberian pupuk pelengkap alkalis dapat meningkatkan $\mathrm{pH}$ tanah, sehingga pemberian pupuk tersebut mampu menimbulkan kondisi lingkungan yang berbeda untuk kebanyakan arthropoda. Menurut Riyanto (2007), kebanyakan arthropoda dapat hidup baik pada $\mathrm{pH}$ netral dan sedikit asam. Kombinasi perlakuan pupuk hayati cair konsentrasi $30 \mathrm{ml} / \mathrm{l}$ dengan pupuk pelengkap alkalis konsentrasi $2 \mathrm{~g} / 1$ memiliki nilai pH 6,94 mendekati pH 7. Gichimu et al. (2008), menyatakan bahwa kelimpahan serangga akan berkurang ketika tempat berlindung dan faktor lingkungan lainnya tidak mencukupi. Dengan demikian kombinasi perlakuan pupuk hayati cair konsentrasi 30 $\mathrm{ml} / \mathrm{l}$ dengan pupuk pelengkap alkalis konsentrasi $2 \mathrm{~g} / \mathrm{l}$ dapat menekan keberadaan arthropoda. 
Tabel 6. Data kepadatan populasi relatif arthropoda 7 MST (\%).

\begin{tabular}{|c|c|c|c|c|c|c|c|c|c|c|c|}
\hline No & Famili & Peranan & H0A0 & H0A1 & H0A2 & H1A0 & H1A1 & $\mathrm{H} 1 \mathrm{~A} 2$ & $\mathrm{H} 2 \mathrm{~A} 0$ & H2A1 & $\mathrm{H} 2 \mathrm{~A} 2$ \\
\hline 1 & Carabidae & Predator & 0,00 & 0,46 & 0,00 & 0,00 & 0,00 & 0,37 & 0,00 & 0,00 & 0,00 \\
\hline 2 & Staphylinidae & Predator & 3,92 & 11,11 & 10,06 & 5,30 & 4,98 & 7,09 & 3,29 & 5,96 & 8,19 \\
\hline 3 & Chrysomelidae & Herbivora & 0,00 & 0,00 & 0,00 & 0,00 & 0,00 & 0,00 & 0,76 & 0,00 & 0,00 \\
\hline 4 & Coccinelidae & Predator & 0,00 & 0,00 & 0,00 & 0,00 & 0,41 & 0,00 & 0,00 & 0,00 & 0,00 \\
\hline 5 & Tephritidae & Herbivora & 3,01 & 2,31 & 2,37 & 2,49 & 2,49 & 2,24 & 1,01 & 1,40 & 2,16 \\
\hline 6 & Agromyzidae & Herbivora & 14,46 & 30,56 & 26,63 & 17,45 & 29,05 & 24,63 & 14,94 & 18,60 & 28,45 \\
\hline 7 & Culicidae & Polinator & 0,90 & 1,39 & 1,78 & 0,62 & 1,24 & 1,12 & 0,76 & 0,70 & 1,29 \\
\hline 8 & Acrididae & Herbivora & 0,30 & 1,39 & 0,00 & 0,00 & 1,24 & 0,37 & 0,25 & 0,00 & 1,72 \\
\hline 9 & Gryllidae & Herbivora & 0,60 & 2,31 & 7,69 & 9,03 & 9,13 & 1,49 & 0,51 & 4,56 & 5,17 \\
\hline 10 & Mantidae & Predator & 0,00 & 0,00 & 0,00 & 0,00 & 0,00 & 0,00 & 0,00 & 0,00 & 0,00 \\
\hline 11 & Formicidae & Predator/Simbion & 42,77 & 15,28 & 22,49 & 39,88 & 22,82 & 30,97 & 57,47 & 42,81 & 18,53 \\
\hline 12 & Vespidae & Polinator & 0,00 & 0,00 & 0,00 & 0,00 & 0,00 & 0,00 & 0,00 & 0,35 & 0,00 \\
\hline 13 & Aleyrodidae & Herbivora & 23,80 & 22,69 & 19,53 & 16,20 & 20,75 & 22,76 & 14,94 & 17,54 & 25,86 \\
\hline 14 & Alydidae & Herbivora & 1,20 & 1,85 & 1,18 & 0,00 & 1,24 & 2,24 & 0,00 & 0,35 & 1,29 \\
\hline 15 & Cicadellidae & Herbivora & 1,20 & 1,85 & 1,78 & 1,25 & 3,73 & 1,49 & 1,01 & 1,05 & 3,45 \\
\hline 16 & Carcinophoridae & Predator & 0,00 & 1,39 & 1,18 & 0,93 & 0,41 & 0,00 & 0,00 & 0,00 & 0,00 \\
\hline 17 & Crambidae & Herbivora & 0,30 & 1,85 & 1,18 & 1,25 & 0,41 & 0,75 & 0,51 & 1,05 & 0,86 \\
\hline 18 & Lycosidae & Predator & 1,51 & 3,70 & 1,78 & 0,62 & 0,41 & 2,61 & 0,51 & 1,40 & 0,86 \\
\hline 19 & Spirostreptidae & Dekomposer & 0,90 & 0,00 & 0,00 & 0,31 & 0,00 & 0,37 & 0,00 & 0,70 & 0,00 \\
\hline 20 & Gomphidae & Predator & 0,30 & 0,00 & 0,00 & 0,00 & 0,00 & 0,00 & 0,00 & 0,00 & 0,00 \\
\hline 21 & Libellulidae & Predator & 0,00 & 0,00 & 0,00 & 0,00 & 0,00 & 0,00 & 0,00 & 0,00 & 0,00 \\
\hline 22 & Entomobrydae & Dekomposer & 3,92 & 0,93 & 1,18 & 2,18 & 0,00 & 0,00 & 0,76 & 0,70 & 0,00 \\
\hline 23 & Rhinotermitidae & Herbivora & 0,90 & 0,93 & 1,18 & 2,49 & 1,66 & 1,49 & 1,27 & 2,81 & 2,16 \\
\hline
\end{tabular}

Tabel 7. Nilai rata-rata keterjadian penyakit downy mildew 4 MST (\%).

\begin{tabular}{|c|c|c|c|c|c|}
\hline \multirow{2}{*}{ Perlakuan } & \multicolumn{3}{|c|}{ Ulangan } & \multirow{2}{*}{ Total } & \multirow[b]{2}{*}{ Rerata } \\
\hline & 1 & 2 & 3 & & \\
\hline H0A0 & 100,0 & 100,0 & 100,0 & 300,00 & 100,00 \\
\hline H0A1 & 100,0 & 100,0 & 100,0 & 300,00 & 100,00 \\
\hline H0A2 & 100,0 & 100,0 & 100,0 & 300,00 & 100,00 \\
\hline H1A0 & 100,0 & 66,7 & 100,0 & 266,70 & 88,90 \\
\hline H1A1 & 100,0 & 100,0 & 100,0 & 300,00 & 100,00 \\
\hline H1A2 & 100,0 & 100,0 & 100,0 & 300,00 & 100,00 \\
\hline $\mathrm{H} 2 \mathrm{~A} 0$ & 100,0 & 66,7 & 100,0 & 266,70 & 88,90 \\
\hline $\mathrm{H} 2 \mathrm{~A} 1$ & 100,0 & 100,0 & 100,0 & 300,00 & 100,00 \\
\hline $\mathrm{H} 2 \mathrm{~A} 2$ & 100,0 & 100,0 & 100,0 & 300,00 & 100,00 \\
\hline
\end{tabular}

Berdasarkan hasil analisis ragam keterjadian penyakit pada 4 MST menunjukkan bahwa perlakuan pupuk hayati cair dan pupuk pelengkap alkalis tidak berbeda nyata dalam menekan keterjadian penyakit downy mildew. Seluruh sampel tanaman pada petak percobaan hampir semuanya menunjukkan keterjadian penyakit. MenurutAgrios (2005), hal yang mendukung terjadinya suatu penyakit pada tanaman sedikitnya harus terjadi kontak dan interaksi antara tiga komponen yaitu tanaman inang, patogen, dan lingkungan yang dikenal sebagai segitiga penyakit. Dengan adanya keterjadian penyakitmemungkinkan keparahan penyakit meningkat Hasil uji BNT pada tarafá $5 \%$ menunjukkan bahwa perlakuan pupuk hayati cair dan pupuk pelengkap alkalis mampu menekan keparahan penyakit downy mildew pada pengamatan 7 MST. Perlakuan pupuk hayati cair konsentrasi $30 \mathrm{ml} / 1$ menunjukkan tingkat keparahan penyakit paling rendah dibandingkan dengan perlakuan konsentrasi lainnya. Perlakuan pupuk pelengkap alkalis konsentrasi $2 \mathrm{~g} / 1$ menunjukkan tingkat keparahan penyakit paling rendah dibandingkan dengan perlakuan konsentrasi lainnya. 
Pupuk hayati cair mengandung mikroorganisme (Pseudomonas sp) yang menguntungkan bagi tanaman dalam menekan pertumbuhan dan perkembangan patogen(Gunarto, 2015). Menurut Dermiyati (2015), Pseudomonas sp. dapat memproduksi antibiotik , sebagai mikroorganisme antagonis patogen di sekitar perakaran, dan memproduksi hormone tumbuhan. Hal ini sejalan dengan penelitian yang dilakukan Rahayu (2009) dalam Putra (2019), menyatakan bahwa mikrorganisme Pseudomonas sp. yang diaplikasikan di lapangan mampu menekan intensitas penyakit pustul Xanthomonas axonopodis pada tanaman kedelai umur 8 minggu rata-rata sangat rendah kurang dari
10\%. Menurut Soesanto et al. (2011) dalam Putra (2019), mikroorganisme antagonis Pseudomonas fluorescens P60 yang telah beradaptasi mampu mengkolonisasi akar tanaman, sehingga mikroorganisme tersebut dapat merangsang tanaman untuk meningkatkan produksi senyawa metabolit sekunder yang berperan dalam ketahanan tanaman terhadap serangan patogen.

Pupuk pelengkap alkalis mengandung banyak unsur hara makro dan unsur hara mikro yang dibutuhkan tanaman. Unsur hara makro yang terkandung dalam pupuk ini adalah N,P,K, Ca, Mg, dan S, sedangkan unsur hara mikro yang terkandung



Gambar 1. Pseudoperonospora cubensis (a) Hifa Pseudoperonospora cubensis, (b) Gejala serangan Pseudoperonospora cubensis.

Tabel 8. Nilai tengah keparahan penyakit tanaman downey mildew 7 MST (\%).

\begin{tabular}{cc}
\hline \multirow{2}{*}{ Perlakuan } & Keparahan penyakit (\%) \\
\cline { 2 - 2 } & $7 \mathrm{MST}$ \\
\hline H0 (tanpa pupuk hayati) & $50,28 \mathrm{a}$ \\
H1 (pupuk hayati $15 \mathrm{ml} / \mathrm{l})$ & $58,33 \mathrm{~b}$ \\
H2 (pupuk hayati 30 ml/1 & $48,94 \mathrm{a}$ \\
\hline BNT & 7,87 \\
\hline A0 (tanpa pupuk alkalis) & $58,80 \mathrm{~b}$ \\
A1 (pupuk alkalis 1 g/l) & $55,29 \mathrm{~b}$ \\
A2 (pupuk alkalis 2 g/l) & $43,45 \mathrm{a}$ \\
\hline BNT & 7,87
\end{tabular}

Keterangan: $\mathrm{H} 0=$ tanpa pupuk hayati cair, $\mathrm{H} 1=$ pupuk hayati cair konsentrasi $15 \mathrm{ml} / \mathrm{l}, \mathrm{H} 2=$ pupuk hayati cair konsentrasi $30 \mathrm{ml} / \mathrm{l}$, $\mathrm{A} 0=$ tanpa pupuk pelengkap alkalis, $\mathrm{A} 1=$ pupuk pelengkap alkalis konsentrasi $1 \mathrm{~g} / 1, \mathrm{~A} 2=$ pupuk pelengkap alkalis konsentrasi $2 \mathrm{~g} / \mathrm{l}$. 
Tabe1 9. Nilai tengah pengaruh interaksi pupuk hayati cair dan pupuk pelengkap alkalis terhadap bobot buah per petak tanaman semangka $(\mathrm{kg})$.

\begin{tabular}{cccc}
\hline Perlakuan H/A & \multicolumn{3}{c}{ Bobot Buah Per Petak $(\mathrm{kg})$} \\
& $\mathrm{A} 0$ & $\mathrm{~A} 1$ & $\mathrm{~A} 2$ \\
\hline H0 & $(8,13) \mathrm{C}$ & $(9,75) \mathrm{C}$ & $(11,89) \mathrm{C}$ \\
& $\mathrm{c}$ & $\mathrm{b}$ & $\mathrm{a}$ \\
$\mathrm{H} 1$ & $(13,46) \mathrm{B}$ & $(13,78) \mathrm{B}$ & $(14,36) \mathrm{B}$ \\
& $\mathrm{b}$ & $\mathrm{ab}$ & $\mathrm{a}$ \\
H2 & $(15,62) \mathrm{A}$ & $(15,64) \mathrm{A}$ & $(17,44) \mathrm{A}$ \\
& $\mathrm{b}$ & $\mathrm{b}$ & $\mathrm{a}$ \\
\hline BNT & & 0,59 & \\
\hline
\end{tabular}

Keterangan: $\mathrm{H} 0=$ tanpa pupuk hayati cair, $\mathrm{H} 1=$ pupuk hayati cair konsentrasi $15 \mathrm{ml} / 1, \mathrm{H} 2=$ pupuk hayati cair konsentrasi $30 \mathrm{ml} / \mathrm{l}$, $\mathrm{A} 0=$ tanpa pupuk pelengkap alkalis, $\mathrm{A} 1=$ pupuk pelengkap alkalis konsentrasi $1 \mathrm{~g} / \mathrm{l}, \mathrm{A} 2=$ pupuk pelengkap alkalis konsentrasi $2 \mathrm{~g} / \mathrm{l}$.

Tabel 10. Hasil analisis $\mathrm{pH}$ tanah.

\begin{tabular}{cccc}
\hline No & Identitas sampel & Unit & $\mathrm{pH}$ \\
\hline 1 & H0A0 & - & 6,23 \\
2 & H0A1 & - & 7,1 \\
3 & H0A2 & - & 7,56 \\
4 & H1A0 & - & 6,96 \\
5 & H1A1 & - & 7,34 \\
6 & H1A2 & - & 7,07 \\
7 & H2A0 & - & 6,96 \\
8 & H2A1 & - & 7,68 \\
9 & H2A2 & - & 6,94 \\
\hline
\end{tabular}

adalah $\mathrm{Fe}, \mathrm{Cl}, \mathrm{Mn}, \mathrm{Cu}, \mathrm{Zn}, \mathrm{Bo}, \mathrm{Na}$, dan Mo (Tim Plant Catalyst, 2014). Kandungan unsur hara tertinggi pada pupuk pelengkap alkalis adalah $\operatorname{Natrium~}(\mathrm{Na})$, unsur hara Natrium $(\mathrm{Na})$ adalah unsur hara fungsional yang dapat menggantikan peran unsur hara kalium $(\mathrm{K})$ seperti yang dikemukakan oleh Sufardi (2012), mengemukakan fungsi kalium secara morfologi adalah meningkatkan resistensi tanaman terhadap serangan hama, patogen, dan kekeringan serta meningkatkan hasil tanaman. Pemberian pupuk pelengkap alkalis bisa menimbulkan lingkungan yang bersifat alkali (basa), dimana $\mathrm{pH}$ rata-rata perlakuan pupuk pelengkap alkalis konsentrasi $2 \mathrm{~g} / \mathrm{l}$ memiliki nilai $\mathrm{pH}>7$. Kondisi tanah dengan $\mathrm{pH}$ tinggi menjadikan kondisi lingkungan tidak sesuai bagi perkembangan patogen, misalnya mengganggu proses rilisnya zoospore sehingga mengurangi kemampuan patogen dalam menginfeksi tanaman (Porth et al., 2003 dalam Hidayah \& Djajadi, 2009). Peningkatan $\mathrm{pH}$ tanah juga dapat menghambat perkecambahan patogen karena spora istirahat dari patogen tersebut dan dapat berkecambah dengan baik jika pH tanah rendah (Agrios, 1997 dalam Hidayah \& Djajadi, 2009). Campbell \& Grethead (1996) dalam Hidayah \& Djajadi (2009), mengemukakan bahwa 
padakondisi $\mathrm{pH}$ tanah yang rendah, patogen lebih bersifat infektif dibandingkan dengan $\mathrm{pH}$ tanah yang tinggi.

Hasil uji BNT pada taraf $\alpha$ 5\% menunjukkan bahwa interaksi perlakuan pupuk hayati cair dengan pupuk pelengkap alkalis berpengaruh nyata terhadap hasil bobot buah per petak. Interaksi perlakuan pupuk hayati cair konsentrasi $30 \mathrm{ml} / 1$ dengan pupuk pelengkap alkalis konsentrasi $2 \mathrm{~g} / 1$ memiliki hasil produksi buah per petak rata-rata seberat $17,44 \mathrm{~kg}$ (Tabel 7). Peningkatan konsentrasi pupuk hayati cair dan konsentrasi pupuk pelengkap alkalis menunjukkan peningkatan hasil bobot buah yang jauh lebih berat dibandingkan tanpa pupuk pelengkap alkalis. Hal ini sejalan dengan penelitian Haq (2018), menyatakan bahwa pemberian pupuk hayati cair dengan konsentrasi 20-30 ml/1 menghasilkan jumlah umbi, jumlah umbi per petak, bobot umbi per sampel, bobot umbi per petak, dan bobot umbi yang layak dijual lebih tinggi bila dibandingkan tanpa pemberian pupuk hayati cair.

\section{KESIMPULAN}

Kenakeragaman arthropoda pada pertanaman semangka setelah perlakuan pupuk hayati cair konsentrasi $15 \mathrm{ml} / 1$ dan pupuk pelengkap alkalis konsentrasi $2 \mathrm{~g} / \mathrm{l}$ memiliki keanekaragaman arthropoda yang paling tinggi dibandingkan dengan perlakuan konsentrasi laiinnya. Penyakit downy mildew adalah penyakit penting tanaman semangka yang ditemukan di lapangan, perlakuan pupuk hayati cair konsentrasi $30 \mathrm{ml} / 1$ dan perlakuan pupuk pelengkap alkalis konsentrasi $2 \mathrm{~g} / \mathrm{l}$ mampu menekan keparahan penyakit downy mildew pada tanaman semangka umur 7 MST.
Interaksi perlakuan pupuk hayati cair konsentrasi 30 $\mathrm{ml} / \mathrm{l}$ dengan pupuk pelengkap alkalis konsentrasi $2 \mathrm{~g} / 1$ memiliki hasil produksi buah perpetak rata-rata $17,44 \mathrm{~kg}$.

\section{SARAN}

Untuk penelitian lanjutan diharapkan lebih meningkatkan pengaruh pupuk hayati cair dan pupuk pelengkap alkalis terhadap intensitas penyakit downy mildew, sebaiknya pemupukan pupuk pelengkap alkalis pada tanaman semangka dilakukan dengan cara semprot agar pemberiannya efektif mengurangi serangan patogen. Selain itu pada pengamatan keterjadian penyakit tanaman, sebaiknya peneliti lanjutan melakukan perhitungan keterjadian penyakit tanaman pada bagian daun.

\section{DAFTAR PUSTAKA}

Agrios, G. N. 2005. Plant Pathology Edisi ke-5. Elseveir Academic Press. New York.

Alao, F.O, Adebayo, T.A, \& Olaniran, O.A. 2016. Population Density of Insect Pests Associated with Watermelon (Citrullus lanatus Thumb) in Southern Guinea Savanna Zone, Ogbomoso. Journal of Entomology and Zoology Studies. 4 (4): 257-260.

Ardiyanti, S. 2019. Keanekaragaman Arthropoda Tanah pada Dua Tipe Pengelolaan Lahan Kopi (Coffea sp) di Kecamatan Gedung Surian Kabupaten Lampung Barat. Skripsi. Universitas Lampung. Lampung.

Badan Pusat Statistik. 2018. Produksi Tanaman Buah-buahan - Semangka (ton) 2018. https://www.bps.go.id. Diakses tanggal 4 Oktober 2019. 
Dermiyati. 2015. Sistem Pertanian Organik Berkelanjutan. Plantaxia. Bandar Lampung.

Fitriana, Y.R. 2006. Keanekaragaman dan Kelimpahan Makrozoobentos di Hutan Mangrove Hasil Rehabilitasi Taman Hutan Raya Ngurah Rai Bali. Biodiversitas ISSN. 7(1): 67-72.

Gichimu B. M., B. O. Owuor \& Dida M. M. 2008. Assessment of four Commercial Watermelon Cultivars and One Local Landrace for Their Response to Naturally Occurring Diseases Pests and Nonpathogenic Disorders in Subhumid Tropical Conditions. ARPN Journal of Agricultural and Biological Science 3. 4(4): 257-260.

Ginting, C. 2013. Ilmu Penyakit Tumbuhan. Lembaga Penelitian Universitas Lampung. Bandar Lampung.

Gunarto, L. 2015. Bio Max Grow Tanaman. Kementrian. Republik Indonesia. Jakarta

Haq, S. H. 2018. Pengaruh Aplikasi Pupuk Mikroba dan Dosis Kompos Jerami terhadap Produksi Bawang Merah (Allium ascalonicum L) Pada lahan Ultisol. Skripsi. Universitas Lampung. Bandar Lampung.

Hidayah, N dan Djajadi. 2009. Sifat - Sifat Tanah yang mempengaruhi Patogen Tular Tanah pada Tanaman Tembakau. Balai Penelitian Tanaman Tembakau dan Serat. Persepektif .8(2): 78-83.

Oka, I.N. 1995. Pengendalian Hama Terpadu dan Implementasinya di Indonesia. Gadjah Mada University Press. Yogyakarta.
Putra, R., N., S. 2019. Analisis Peningkatan Hasil Tanaman Cabai (Capsicum annuum L.) dengan Perlakuan Mulsa dan Pupuk Cair mikroba terdampak Hama dan Patogen. Skripsi. Universitas Lampung. Bandar Lampung.

Richards, L.A., Dyera, L.A., Foriestera, M.L., Smillanicha, A.M., Dobson, C.D., Leonard, M.B., \& Jeffrey, C.S. 2015. Phytochemical Diversity Drives Plant-insect Community Diversity. PNAS . 112(35): 10973-10978.

Riyanto. 2007. Kepadatan, Pola Distribusi dan Peranan Semut pada Tanaman di sekitar Lingkungan Tempat tinggal. Jurnal Penelitian Sains. 10(2): 241-253.

Soegianto, A. 1994. Ekologi kuantitatif: Metode Analisis Populasi dan Komunitas. Penerbit Usaha Nasional. Jakarta.

Subekti, N. 2012. Keanekaragaman Jenis Serangga di Kawasan Hutan Tinjomoyo Semarang Jawa Tengah. Skripsi. Fakultas MIPAUniversitas Negeri Semarang. Semarang.

Sufardi. 2012. Pengantar Nutrisi Tanaman. Bina Nanggroe. BandaAceh.

Tambunan, Maria., M., Uly, Mena., Hasanuddin. 2013. Indeks Keanekaragaman Jenis Serangga Pada Tanaman Tembakau ( Nicotina tabaccum L.) di kebun Helvetia PT Perkebunan Nusantara II. Jurnal Agroekoteknologi. 2(1): 225-238.

Tim Plant Catalyst. 2014. Buku Panduan Produk Plant Catalyst 2006. PT Citra Nusa Insan Cemerlang. Jakarta. 